\title{
Implementation of the Constitutional Court Decision Regarding the Execution of Fiduciary Guarantees and Inclusion of Default Clauses in Indonesia
}

\author{
Siti Malikhatun Badriyah", R. Suharto, Marjo, Retno Saraswati and \\ Muhammad Shafiyuddin Wafi
}

\author{
Faculty of Law Diponegoro University, Semarang 50275, Indonesia
}

\begin{abstract}
The existence of the Constitutional Court Decision Number 18/PUU-XVII/2019, made problems in society related to the implementation of the fiduciary guarantee execution. This study aims to determine and analyze the implementation of the Constitutional Court Decision Number 18/PUU-XVII/2019. The research method used is normative juridical by conducting document studies of legal principles, legal regulations and legal norms in Indonesia and interviews with civil law experts. The results showed that the decision of the Constitutional Court Number 18/PUUXVII/2019, caused disagreements in its implementation. Prior to the Constitutional Court Decision, the execution of the Fiduciary Guarantee was based on the Fiduciary Guarantee Law, if the debtor in default, the Fiduciary Recipient can execute on the basis of the fiduciary recipient's own power to sell the object of fiduciary security, but with a Constitutional Court Decision it must go through a court. This creates confusion for creditors and is against the principle of material security. This is detrimental to creditors, because creditors cannot immediately sell their own fiduciary collateral objects if the debtor defaults. This phenomenon can lead to a lack of legal certainty and legal protection for fiduciary recipients and contradicts the nature of fiduciary guarantees which should have strong guarantee rights and are easy to implement.
\end{abstract}

Keywords: Fiduciary Guarantee, Execution, Default Clauses, Implementation.

\section{INTRODUCTION}

Guarantee in Indonesia is very much needed in contract implementation (Hartono, 2019). Likewise with other countries in the world. It was also pointed out by Bidabad, (2017); Kim, (2019) that the use of this guarantee was growing so rapidly and this guarantee was very important in paying for business activities. One of them is in financing activities for businesses and consumers. One of them is the distribution of funds from financing companies for debtors. Furthermore, the debtor making payments in installments carries a large risk. In the debt agreement, default often occurs because the debtor is unable to pay or does not want to (Ostrom \& lacobucci, 1998; Bhanot, 2017). Therefore, a guarantee is needed. One of them is a material guarantee. The granting of fiduciary guarantees is carried out through a process called the Constitutum Prossesorium, which means that there is a transfer of ownership of the object without physically surrendering the object. The transfer of property rights in this case is not intended to be permanent, but only as a guarantee for the implementation of the debtor's restoration. Thus, if the principal agreement ends, the ownership rights over the property will be returned to the grantor of the fiduciary (Gai et al., 2016).

*Address correspondence to this author at the Faculty of Law Diponegoro University, Semarang 50275, Indonesia; Tel: +622476918201;

E-mail: smbadriyah.fh.undip@gmail.com
Previous research has shown that fiduciary guarantees create huge benefits for the parties. Fiduciary guarantees create huge benefits for the parties. For fiduciary recipients, the existence of a fiduciary guarantee can guarantee the security of their debts. On the other hand, for the fiduciary, fiduciary guarantees provide benefits because the object remains in his/her control, so that it can be used, especially if the object is merchandise or equipment for business (Badriyah et al., 2019). This is also found in the research of Sanusi (2017) and Syafrida \& Hartati (2020).

Although fiduciary guarantees provide great benefits in the economy, especially in the development of the business world, however, there are often various legal issues, including regarding the implementation of fiduciary guarantee execution arrangements if the debtor defaults

In Article 15 Paragraph (2) of the Fiduciary Guarantee Law, it is stated that "the fiduciary guarantee certificate has the same executorial power as a court decision which has permanent legal force." This implies that if the debtor is in default, the fiduciary should be able to carry out direct execution without court mediation. This is further regulated in Article 29 of the Fiduciary Guarantee Law which regulates 3 ways of executing fiduciary guarantees if the debtor defaults, which gives power to creditors to execute objects of fiduciary guarantee without court mediation. 
Research on the phenomenon of implementing the decision of the constitutional court number 18 / PUUXVII / 2019 shows that the execution of the fiduciary security object must go through court mediation if the fiduciary guarantee deed does not include a default clause and no voluntary submission of the fiduciary guarantee object from the donor fiduciary. This is contrary to the principles of fiduciary security and the Fiduciary Guarantee Law which makes it easy for creditors to execute the object of fiduciary collateral if the debtor is in default. This is very detrimental to creditors and creates legal uncertainty in the execution of the fiduciary guarantee.

This research uses the juridical normative method by examining legal principles, legal regulations, legal norms and the implementation of legal regulations regarding the execution of fiduciary guarantees. The method is used with the aim of obtaining data regarding the comparison of the implementation of fiduciary guarantees in Indonesia in terms of default debtors, before and after the Constitutional Court Decision $18 /$ PUU-XVII / 2019.

\section{MATERIAL}

The Fiduciary Guarantee is one of the materials guarantees. Thus, fulfilling the characteristics as material security. Specific regulations regarding this fiduciary guarantee are contained in the Fiduciary Guarantee Act. The regulation of fiduciary security in this law is in line with the principles of material security in the general provisions in the Civil Code. In Article 1131 of the Civil Code (KUH Perdata) states that, "All objects of a debtor, both movable and immovable, both existing and new ones will exist in the future, become a guarantee for all debtor personal engagements such." In Article 1131 Civil law is laid down the general principle of a creditor's rights against his debtor (Kamello \& Fidusia, 2014.). Thus, all debtors' wealth becomes collateral for debtor's debts to creditors. The article shows that everyone is responsible for their debts, this responsibility is in the form of providing their assets, both movable and immovable objects, and if necessary, they are sold to pay off their debts (schuld and haftung principles) (Badrulzaman, 1991).

From the provisions of Articles 1131 and 1132 K.U.H. Civil law shows the creditorium parity principle. This means that the position of all creditors to all assets owned by the debtor is the same. Thus, the general principle is contained, namely the existence of equal rights of creditors to the assets of debtors. Payment of creditors' receivables is based on the principle of balance, namely that each receives payment proportionately according to the size of the respective receivables.

The legitimate reasons for giving priority to receivables mentioned in Article 1132 are exceptions to the general principle. The valid reasons are if there are receivables with privilege rights, liens, and mortgages. Repayment of these receivables must be prioritized. Creditors whose payment of accounts payable takes precedence over creditors are called preferred creditors (Badriyah et al., 2018). One of them is the fiduciary recipient creditors. Although fiduciary security is not stated in the Civil Code, because it has characteristics such as pawning and mortgages, namely as material security, the position of the creditor is also the preferred creditor. Usually, guarantees in business relationships, especially in financing institutions are made in the form of fiduciary transfer of ownership (Fiduciary) (Fuady, 2013). The granting of fiduciary guarantees is carried out through a process called the Constitutum Prossesorium (surrender of ownership of objects without giving up the physical objects) (Fuady, 2002). In connection with this fiduciary guarantee, the physical object remains in the hands of the owner or the debtor.

The fiduciary guarantee institution has characteristics, namely: a) The fiduciary guarantee has the character of an 'accessoir', meaning that the fiduciary guarantee is an additional agreement to the main agreement; b) Creditors receiving fiduciary have a preferred position (Article 27 of the Fiduciary Guarantee Act), which means that the creditor has the right to take repayment of the debt on the result of the execution of the fiduciary object to take precedence over other creditors; c) Always adhere to the object that is guaranteed in the hands of whoever it is (droit de suite) (Article 20 of the Fiduciary Guarantee Act); d) As material collateral, because there are certain objects that are the object of collateral. An object is a movable object as well as immovable objects that cannot be encumbered with Mortgage Rights (Article 1 point 2 of the Fiduciary Guarantee Law). The object should be in the form of immovable objects not only that cannot be encumbered by a mortgage but also a mortgage; e) Is strong security right. This is because Creditors receiving Fiduciary duties have the position of preferred creditors, namely creditors whose payment of receivables is prioritized over other creditors. Also, the creditors of the Fiduciary Receiver also have the position of separatist creditors, namely creditors who 
are not affected by the debtor's bankruptcy. f) Easy and sure execution of the execution. If the debtor is in default, the creditor can sell the fiduciary object without having to go through a lawsuit to the court. The execution of the Fiduciary Guarantee is regulated in Articles 29-34 of the Fiduciary Guarantee Law.

\section{METHOD}

This study uses a normative juridical method by conducting literature research to obtain secondary data relating to the arrangement for the execution of fiduciary security. With this research method is intended to find and analyze the comparison between the execution of fiduciary guarantees before the Constitutional Court decision Constitutional Court decision 18 / PUU-XVII / 2019 which is based on the principles of fiduciary guarantee, as generally regulated in the Civil Code and specifically in the Fiduciary Guarantee Act, with the execution of a fiduciary guarantee of the existence of the Constitutional Court Decision.

\section{RESULT}

The results of the research show that in the Constitutional Court, the Constitutional Court Decision 18 / PUU-XVII / 2019 on January 6, 2020 decided in its decision, among others, that:

"Article 15 paragraph (2) of the Fiduciary Guarantee Law insofar as the phrase" executorial power "and the phrase" equal to a court decision having permanent legal force "is contrary to the 1945 Constitution of the Republic of Indonesia and has no binding legal force, as long as it is not interpreted "against the fiduciary guarantee where there is no agreement on default (default) and the debtor objected to voluntarily hand over the object of the fiduciary guarantee. Thus, all legal mechanisms and procedures in the execution of the Fiduciary Guarantee Certificate must be carried out and apply the same as the execution of court decisions that have permanent legal force."

This shows that there is a difference between the execution of fiduciary guarantees before the Constitutional Court Decision 18 / PUU-XVII / 2019 and after the Constitutional Court Decision. This difference can be seen in Table 1.

\section{DISCUSSION}

\section{Implications of the Decision of the Constitutional Court Number 18/PUU-XVII/2019 Regarding the Execution of Fiduciary Collateral in the Case of Default Debtors}

The implication of the Constitutional Court Decision number 18 / PUU-XVII / 2019 resulted in significant differences in the implementation of the fiduciary

Table 1: Differences in Execution Execution

\begin{tabular}{|c|c|c|c|}
\hline & & Before the Constitutional Court Decision & After the Constitutional Court Decision \\
\hline 1 & $\begin{array}{l}\text { Legal basis for } \\
\text { execution }\end{array}$ & Civil Code, Fiduciary Guarantee Act & $\begin{array}{c}\text { Based on the Civil Code, Fiduciary Guarantee Act, } \\
\text { Constitutional Court Decisions }\end{array}$ \\
\hline 2 & Character & General nature & $\begin{array}{l}\text { For a case filed based on a lawsuit regarding the execution } \\
\text { case of fiduciary security at the Financing Company }\end{array}$ \\
\hline 3 & $\begin{array}{l}\text { Execution of } \\
\text { execution }\end{array}$ & $\begin{array}{l}\text { There are } 3 \text { ways: } \\
\text { 1. Based on the executorial title on the } \\
\text { fiduciary guarantee certificate } \\
\text { 2. Based on the power of the Fiduciary to sell } \\
\text { the fiduciary security object } \\
\text { 3. Underhand sale of agreement between } \\
\text { giver and recipient of fiduciary } \\
\text { Direct execution can be carried out without } \\
\text { court mediation (In accordance with Article } 15 \\
\text { paragraph (2) of the Fiduciary Guarantee Law) }\end{array}$ & $\begin{array}{c}\text { It cannot be done without court intercession, unless there } \\
\text { is a clause regarding default on the Fiduciary Security } \\
\text { Deed and the Fiduciary Giver's debtor voluntarily submits } \\
\text { the object of the Fiduciary Guarantee } \\
\text { Contrary to Article } 15 \text { Paragraph (2) of the Fiduciary } \\
\text { Guarantee Law }\end{array}$ \\
\hline 4 & Consequence & There is more legal certainty & $\begin{array}{c}\text { This results in different interpretations, so there is less } \\
\text { legal certainty }\end{array}$ \\
\hline 5 & $\begin{array}{l}\text { Legal Protection of } \\
\text { the Parties }\end{array}$ & Provides strong legal protection to creditors & Providing legal protection to debtors \\
\hline
\end{tabular}


guarantee execution. Execution before the Constitutional Court decision gives authority to the creditors who receive the fiduciary to carry out direct execution of the object of the fiduciary guarantee in the event the debtor is in default. This is in accordance with the principle of the material guarantee which gives a strong position to creditors who receive the material guarantee as stipulated in Article 1132 of the Civil Code. In this case, the creditors holding the material security have a position as preferred creditors. If the debtor is in default, the fiduciary guarantee can be executed without the mediation of a judge in court. Regarding the execution of the fiduciary guarantee, creditors can also sell the object of the fiduciary guarantee directly without court mediation. This is confirmed in Article 15 Paragraph (2) of the Fiduciary Guarantee Law and Article 29 of the Fiduciary Guarantee Law. In carrying out the execution of the fiduciary guarantee, the debtor is obliged to submit the object of the fiduciary guarantee.

One of the most important factors in implementing the agreement between the parties is the existence of a guarantee. Collateral is needed for the security of creditors' accounts. One of the guarantees widely used by the community is fiduciary security. Fiduciary security is a material guarantee. Therefore, certain objects that are the object of collateral. Many properties and assets can be used as guarantees for observing obligations (Bidabad, 2017). Classification of objects within the framework of the legal system of objects is indispensable for fiduciary security institutions to provide legal certainty for objects of fiduciary security (Kamsilaniah et al., 2018). As a guarantee of materiality, a fiduciary guarantee creates material rights. Material rights are rights that give direct power over an object. As one of the material rights that provide guarantees, fiduciary security also has the characteristics of material rights in general. One of them is that material rights are absolute, meaning that they can be defended against anyone. Thus, the creditor who holds the material security also has the right to defend his rights against anyone. One of them is the right of execution in the case of the debtor in default.

Based on Article 15 Paragraph (2) "The Fiduciary Guarantee Certificate has the same executorial power as a court decision which has permanent legal force". In Article 15 Paragraph (3) of the Fiduciary Guarantee Law, it is stated that "If the debtor fails to promise, the Fiduciary has the right to sell the object which is the object of the Fiduciary Guarantee under his power".
This is following the principle of material security which is a strong guaranteeing right and is easy to implement. If the debtor is in default, the creditor can sell the object of fiduciary security at his power. This means that in such a case it does not require court mediation. This is also expressly regulated in Article 29 of the Fiduciary Guarantee Law, regarding one of the executions of the fiduciary security object if the debtor is in default is to sell the object of the fiduciary security object at the debtor's power, and take the payment of the debt from the proceeds from the sale of the object.

On January 6, 2020, the Constitutional Court decided in its decision, among others, that "Article 15 paragraph (2) of the Fiduciary Guarantee Law as long as the phrase" executorial power" and the phrase "equal to a court decision having permanent legal force" is contrary to the Law. The basis of the Republic of Indonesia in 1945 and does not have binding legal force as long as it is not interpreted: "against fiduciary guarantees where there is no agreement on default and the debtor objected to voluntarily handing over the object which became fiduciary guarantee, then all legal mechanisms and procedures in carrying out the execution The Fiduciary Guarantee Certificate must be carried out and the same applies to the execution of court decisions which have permanent legal force".

In practice, there are various interpretations of the Constitutional Court decision which in turn creates legal uncertainty in its implementation. On the one hand, there is an interpretation that the Constitutional Court decision is not in following principles of material guarantee. The existence of a material guarantee should provide convenience and legal certainty for creditors in executing the object of collateral in the event that the debtor is in default. However, the decision of the Constitutional Court is precisely intended that the execution of the object of fiduciary security uses court mediation if there is no default formula in the deed and the debtor is unwilling to submit voluntarily. Whereas it should be based on the principle of agreement law, if the debtor does not fulfill the obligations stipulated in the agreement, then there will be the default. This can be seen from the forms of default which include three things, namely: 1) the debtor does not make achievements; 2) the debtor is late in making achievements; 3 ) the debtor performs the achievement but is not in accordance with the agreement; 4) the debtor does things that are prohibited in the agreement. Thus, if it meets one of the forms of default, it can be said to have committed default. Thus, even without the formulation of a default 
clause, without fulfilling the achievements, the debtor will automatically commit default. On the other hand, there is an interpretation that the Constitutional Court Decision is very appropriate because it can protect the debtor from arbitrary actions by the creditor by forcibly taking the object of guarantee in the event that the debtor is in default and does not want to voluntarily hand over the object. According to Efferin (2020), this Constitutional Court decision provides a sense of justice for debtors but can have an economic impact on the business world in Indonesia.

These differences in views can lead to legal uncertainty and a lack of legal protection for the parties. If we return to the legal principle of guarantee that the importance of the guarantee institution is to ensure the security of creditors' receivables and provide legal protection for creditors, creditors should have their rights as collateral rights holders. In the event that what is owned is a material guarantee, then one of the rights obtained by the creditor is to sell the object of guarantee if the debtor is in default. Default means that the debtor does not meet the achievement. There are three forms of achievement, namely giving something, doing something and not doing something, that is prohibited by law. The importance of guarantees is to ensure the performance of the debtor's achievements.

Based on these principles, with the debtor default, the creditor receiving the fiduciary should be able to carry out the execution based on Article 29 Paragraph (1) states that "if the debtor or Fiduciary Provider fails to promise, the execution of the object which is the object of the Fiduciary Guarantee can be carried out by: a) implementation of the executorial title as referred to in Article 15 paragraph (2) by the Fiduciary Recipient"; b) the sale of Objects which are the object of the Fiduciary Guarantee under the authority of the Fiduciary himself through a public auction and collect the receivables from the sale proceeds; c) underhand sales made based on the agreement of the Giver and Recipient of Fiduciary if in this way the highest price that is favorable to the parties can be obtained".

Furthermore, Article 29 Paragraph (2) states that "The sale as referred to in paragraph (1) letter c is carried out after 1 (one) month has passed since being notified in writing by the Fiduciary Giver and/or Recipient of Fiduciary to interested parties and announced at least in 2 (two) newspapers circulating in the area concerned".

If $t$ the debtor is in default, the fiduciary execution can be carried out and the fiduciary is obliged to submit the object which is used as the object of the fiduciary guarantee in the execution of the fiduciary guarantee (Suprabowo et al., 2017). This was also stated by Alizon (2020). This is under the provisions of Article 30 of the Fiduciary Guarantee Law which states that "the Fiduciary Giver is obliged to hand over the Objects which are the object of the Fiduciary Guarantee in the context of the execution of the Fiduciary Guarantee". If the fiduciary does not submit the fiduciary security object at the time of execution, the guarantor has the right to take the fiduciary security object. If the fiduciary does not want to hand over the object, the fiduciary can ask for help from the authorities.

The decision of the Constitutional Court regarding the default clause that must be formulated in the deed is inaccurate and does not provide legal protection to the creditors who receive fiduciaries. Apart from that, the connection with the execution of fiduciary guarantees also raises various interpretations. Some argue that the execution of fiduciary guarantees must be carried out by the court. On the other hand, believe that they can carry out the execution without court mediation. This creates legal uncertainty in the execution of the fiduciary guarantee.

\section{CONCLUSION}

The implementation of the Constitutional Court Decision Number 18/PUU-XVII/2019 has created a lack of legal certainty and legal protection for creditors. In addition, the decision contradicts the principle of material guarantee, which should allow the creditor to carry out the execution based on his own power without going through court in the case of the debtor in default, it turns out that in this decision there is a requirement to include a default clause and the debtor voluntarily submits the object of guarantee. It should be based on the principle of contract law, if the debtor does not fulfill the obligations stipulated in the agreement, and then there will be default.

\section{ACKNOWLEDGEMENTS}

The author would like to thank the Chancellor of Diponegoro University, the Dean of the Faculty of Law, Diponegoro University, the Institute for Research and Community Service, and all parties who have provided assistance, suggestions and input to the author.

\section{REFERENCES}

Alizon, J. (2020). Rekonstruksi Pelaksanaan Eksekusi Jaminan Fidusia Pasca Putusan Mahkamah Konstitusi Nomor 18/PUU-XVII/2019. Eksekusi, 2(1), 58-82. https://doi.org/10.20473/ntr.v2i1.13167 
Badriyah, S. M., Mahmudah, S., Soemarmi, A., \& Kamello, T. (2019). Leasing Agreement on Financing SMEs in Fisheries Industry. Journal of Legal, Ethical and Regulatory Issues, 22(3), 1-7.

Badriyah, S., Mahmudah, S., Marjo, M., \& Kashadi, K. (2018). The Re-Orientation of Use Option Right in the Financial Lease Contract for Small and Medium Enterprises Development in Indonesia. International Journal of Mechanical Engineering and Technology, 9(3): 581-591.

Bhanot, S. P. (2017). Cheap promises: Evidence from loan repayment pledges in an online experiment. Journal of Economic Behavior \& Organization, 140, 246-266. https://doi.org/10.1016/j.jebo.2017.04.007

idabad, B. (2017). Mortgage Securitization System (MSS) (a complementary system of Rastin Banking). International Journal of Law and Management, 59(6), 778-783. https://doi.org/10.1108/IJLMA-05-2016-0045

Badrulzaman, M. D. (1991). Mencari Sistem Hukum Benda Nasional. Bandung: Alumni.

Efferin, James Ridwan. "Eksekusi Objek Jaminan Fidusia Pasca Putusan Mahkamah Konstitusi Nomor 18/PUU/XVII/2019." Yuriska: Jurnal IImu Hukum 12, no. 1 (2020): 39-49. https://doi.org/10.24903/yrs.v12i1.789

Fuady, M. (2002). Pengantar hukum bisnis: Menata bisnis modern di era global. Bandung: Citra Aditya Bakti.

Fuady, M. (2013). Hukum Jaminan Utang. Jakarta: Penerbit Erlangga.

Gai, L., Ielasi, F., \& Rossolini, M. (2016). SMEs, public credit guarantees and mutual guarantee institutions. Journal of Small Business and Enterprise Development. 23(4), 12081228. https://doi.org/10.1108/JSBED-03-2016-0046
Hartono, A. P. (2019). Credit Agreement with Fiduciary Collateral in the Form of a Patent in the Perspective of Indonesian Law. Humanities \& Social Sciences Reviews, 7(5), 71-75. https://doi.org/10.18510/hssr.2019.759

Kamello, T., \& Fidusia, H. J. (2014). Suatu Kebutuhan yang didambakan. Bandung: Alumni.

Kamsilaniah; Abbas, Nurhayati; Patittingi, Farida; Miru, Ahmadi. (2018). The Existence of Stage House as Fiduciary Guarantee: Perspective of Horizontal Separation Principle. JL Pol'y \& Globalization, 75, 116.

Kim, S. M. (2019). Reduction clause in an advance payment guarantee (AP-bond) under an overseas construction contract. Journal of Korea Trade, 23(1), 35-49. https://doi.org/10.1108/JKT-06-2018-0050

Ostrom, A., \& lacobucci, D. (1998). The effect of guarantees on consumers' evaluation of services. Journal of Services Marketing, 12(5), 362-378. https://doi.org/10.1108/08876049810235405

Sanusi, S. (2017). Legal Protection of the Creditor on Fiduciary Guarantee Objects Unlisted in the Fiduciary Registration Office. International Journal of Law Reconstruction, 1(1), 7486. https://doi.org/10.26532/ijlr.v1i1.1636

Suprabowo, B., Mashdurohatun, A., \& Suparman, E. (2017). The Inhibiting Factors On Legal Protection For Recipients Of Fidusiary Warranties With Inventory Guaranted Objects. South East Asia Journal of Contemporary Business, Economics and Law, 13, 2289-1560.

Syafrida, S., \& Hartati, R. (2020). Eksekusi Jaminan Fidusia Setelah Putusan Mahkamah Konstitusi Nomor 18/Puu/Xvii/2019. Adil: Jurnal Hukum, 11(1). https://doi.org/10.33476/ajl.v11i1.1447

Received on 05-12-2020

DOI: https://doi.org/10.6000/1929-4409.2021.10.05

\section{(c) 2021 Badriyah et al.; Licensee Lifescience Global.}

This is an open access article licensed under the terms of the Creative Commons Attribution Non-Commercial License (http://creativecommons.org/licenses/by-nc/3.0/) which permits unrestricted, non-commercial use, distribution and reproduction in any medium, provided the work is properly cited. 